\title{
Hubungan Pengetahuan Ibu tentang "Isi Piringku" dengan Kejadian Stunting Anak Balita Usia 12-59 Bulan
}

\section{Relationship Of Mother Knowledge About Isi Piringku" with The Incidence Stunting Of Children Age 12-59 Months}

\author{
Ade Devriany ${ }^{1}$, Diah Ayu Wulandari ${ }^{2}$ \\ Jurusan Gizi, Politeknik Kesehatan Kementerian Kesehatan Pangkalpinang, Indonesia
}

\section{ARTICLE INFO}

\section{Article history}

Received date

08 Feb 2021

Revised date

19 Mar 2021

Accepted date

06 Apr 2021

\section{Keywords:}

Isi Piringku;

Knowledge;

Stunting;

Toddler.

\section{Kata kunci:}

Isi Piringku;

Pengetahuan;

Stunting;

Balita.

\author{
ABSTRACT/ ABSTRAK
}

\begin{abstract}
A toddler is an age group that is prone to nutrition and disease. The handling of stunting in the Bangka Belitung Islands Province is a priority in Bangka Regency. Mendo Village has the highest percentage of stunting, which is $17,7 \%$. The purpose of this study is to analyze the relationship mother's knowledge about Isi Piringku with the nutritional status of children aged 12-59 months in Mendo Village, Mendo Barat Subdistrict. The design of this study was a cross-sectional study which was conducted in Mendo Village, Mendo Barat Subdistrict. The number of samples used was 96 mothers and toddlers aged 12-59 months Data analysis used univariate and bivariate analysis with chi-square statistical tests. The results of this study are More toddler mothers have good knowledge about Isi Piringku is $64,6 \%$ (62 people), while the nutritional status of stunting toddlers is $6 \%$ (6 people). There is no correlation between mother's knowledge about Isi Piringku with the nutritional status of children age 12-59 months in Mendo Village, Mendo Barat Subdistrict with a $\mathrm{p}$-value $=0,125$ ( $\mathrm{p}$-value $>0,05$ ). This happens because the respondent has toddlers with normal nutritional status but the respondent has less knowledge about Isi Piringku, and vice versa being influenced by economic factors/work, education, age, and environment.
\end{abstract}

Balita merupakan kelompok umur yang rawan gizi dan rawan penyakit. Penanganan stunting di Provinsi Kepulauan Bangka Belitung yang menjadi prioritas salah satunya adalah Kabupaten Bangka. Desa Mendo merupakan lokasi khusus penanganan stunting dengan persentase sebesar $17,7 \%$. Tujuan dari penelitian ini yaitu untuk menganalisis hubungan pengetahuan ibu tentang Isi Piringku dengan status gizi anak balita usia 12-59 bulan di Desa Mendo Kecamatan Mendo Barat. Rancangan penelitian yang digunakan cross sectional study dengan jumlah sampel yaitu 96 ibu dan balita berusia 12-59 bulan. Analisis data yang digunakan analisis univariat dan bivariat dengan uji statistik chi square. Hasil dari penelitian ini yaitu ibu balita lebih banyak yang memiliki pengetahuan baik tentang Isi Piringku yaitu sebesar 64,6\% (62 orang), sedangkan status gizi balita yang stunting sebesar $6 \%$ (6 orang). Tidak ada hubungan pengetahuan ibu tentang isi piringku dengan status gizi anak balita usia 12-59 bulan di Desa Mendo Kecamatan Mendo Barat dengan nilai $p$-value $=0,125$ ( $p$-value $>0,05)$. Hal ini terjadi karena responden memiliki balita dengan status gizi normal tetapi responden memiliki pengetahuan kurang tentang Isi Piringku, begitupun sebaliknya yang dipengaruhi oleh faktor ekonomi atau pekerjaan, pendidikan, umur dan lingkungan.

Corresponding Author:

Ade Devriany

Jurusan Gizi, Politeknik Kesehatan Kementerian Kesehatan Pangkalpinang, Indonesia

Email: adevriany@yahoo.com

\section{PENDAHULUAN}

Masa balita merupakan masa kehidupan yang sangat penting dan perlu perhatian yang serius. Pada masa ini berlangsung proses tumbuh kembang yang sangat pesat yaitu pertumbuhan fisik dan perkembangan psikomotorik, mental dan sosial (Almatsier, 2012). Pada saat ini, balita (bawah lima tahun) sebagai generasi penerus bangsa yang diharapkan menjadi sumber daya 
manusia yang berkualitas di masa depan memerlukan perhatian khusus. Usia di bawah lima tahun merupakan "usia emas" dalam pembentukan sumberdaya manusia baik dari segi pertumbuhan fisik maupun kecerdasan, dimana hal ini harus didukung oleh status gizi yang baik karena status gizi berperan dalam menentukan sukses tidaknya upaya peningkatan sumber daya manusia.

Menurut Rahmawati (2018), masa balita sering dinyatakan sebagai masa kritis untuk optimalisasi pertumbuhan dan perkembangan otak yang sangat dipengaruhi oleh pola asuh orang tua, salah satunya dalam pola pemberian makan sebagai pintu masuk pemenuhan berbagai kebutuhan unsur zat gizi. Akan tetapi, ada kalanya pola pemberian makan yang kurang baik dapat memengaruhi status gizi balita tersebut. Hasil penelitian menyatakan bahwa terdapat hubungan antara pengetahuan pola pemberian makan dengan status gizi balita (Rahmawati, 2018). Masalah gizi dapat terjadi pada semua kelompok umur. Anak balita merupakan kelompok umur yang rawan gizi dan rawan penyakit. Hal ini disebabkan karena anak balita sedang berada dalam masa transisi dari makanan bayi ke makanan dewasa. Banyaknya masalah gizi terjadi di Indonesia menurut UNICEF (2012) sebanyak $40 \%$ anak balita di pedesaan terhambat pertumbuhannya. Berdasarkan Global Nutrition Report (2014), Indonesia termasuk ke dalam 17 negara di antara 117 negara yang memiliki ketiga masalah gizi, yaitu stunting, wasting dan overweight.

Prevalensi balita stunting di Provinsi Kepualauan Bangka Belitung mengalami peningkatan dari $21,9 \%$ tahun 2016 menjadi 27,3\% tahun 2017. Berdasarkan data Tim Nasional Percepatan Penanggulangan Kemiskinan pada tahun 2018, terdapat 160 Kabupaten/Kota menjadi prioritas dengan masing-masing 10 Desa untuk penanganan stunting (kerdil) (Direktorat Jenderal Bina Gizi Masyarakat, 2018). Adapun untuk penanganan stunting di Provinsi Kepulauan Bangka Belitung yang menjadi prioritas salah satunya adalah Kabupaten Bangka. Berdasarkan data hasil Pemantauan Status Gizi tahun 2015-2017 menunjukkan jumlah balita yang mengalami stunting di Kabupaten Bangka terus meningkat (Dinas Kesehatan Provinsi Bangka Belitung, 2017).

Puskesmas Petaling adalah Puskesmas yang memiliki wilayah kerja yang tersebar di Kecamatan Mendo Barat. Kecamatan Mendo Barat memiliki 3 desa yang menjadi lokasi utama penanganan stunting yaitu Desa Mendo, Desa
Cengkong Abang, dan Desa Air Duren. Dari ketiga lokasi utama tersebut, Desa Mendo memiliki persentase angka stunting tertinggi yaitu $17,7 \%$.

Status gizi pada masyarakat dipengaruhi oleh banyak faktor. Kondisi sosial ekonomi merupakan salah satu faktor penting yang memengaruhi status gizi. Bila kondisi sosial ekonomi baik maka status gizi diharapkan semakin baik. Status gizi anak balita khususnya kejadian stunting akan berkaitan erat dengan kondisi sosial ekonomi keluarga (orang tua), antara lain pendidikan orang tua, pekerjaan orang tua, jumlah anak orang tua, pengetahuan dan pola asuh ibu serta kondisi ekonomi orang tua secara keseluruhan (Supariasa, 2012).

Hasil penelitian Yabanci, dkk (2014), menunjukkan bahwa ibu yang memiliki pengetahuan gizi lebih tinggi memiliki anak dengan status gizi nornal, sehingga tingkat pengetahuan ibu memengaruhi kebiasaan makan anak. Penelitian tersebut sejalan dengan penelitian dari Al-Shookri (2011) yang menunjukkan bahwa, ibu dengan tingkat pengetahuan gizi yang rendah memiliki anak dengan kecukupan asupan makanan yang rendah, sehingga pengetahuan ibu terkait gizi mendukung status gizi anak.

Ibu memiliki peranan dan pengaruh yang besar terhadap keadaan gizi balita. Perkembangan kejiwaan setiap anak pada awal kehidupannya sangat tergantung pada orang tua terutama ibu, yang melahirkan dan yang pertama membantu segala keperluannya. Pengaruh pertama yang mempunyai kesan kuat adalah apa yang diperoleh pada awal kehidupan sampai anak berusia lima tahun. Jika pada usia awal, yang diterima dan dilihat adalah suasana kotor dan tidak sehat, serta tidak menunjukkan perilaku yang sadar akan pentingnya gizi tentunya awal kehidupannya akan terisi dengan kesan yang kurang mendukung perkembangan dirinya secara positif, sehingga dapat menurunkan kesehatannya (Mulyono, 2000).

Pemerintah mengeluarkan sebuah Pedoman Gizi Seimbang dalam upaya menurunkan dan menjaga status gizi masyarakat. Tanggal 27 Januari 2014 Pedoman Gizi Seimbang mengalami pembaharuan dengan penambahan media promosi "Tumpeng" dan "Isi Piringku" (Kementerian Kesehatan RI, 2014). Upaya promosi kesehatan melalui pendekatan pendidikan dengan media promosi. Media promosi kesehatan adalah alat bantu untuk menampilkan pesan atau informasi dan mengunakan alat-alat pendukung. Media dijadikan sebagai alat bantu untuk mengatasi 
keterbatasan pengalaman yang dimiliki oleh para masyarakat dan menjadi pedoman bagi masyarakat dalam merubah perilaku ke arah gizi seimbang. Penggunaan media dapat dikatakan efektif ketika komunikasi dengan media juga dapat mengubah atau memengaruhi perilaku seseorang. Jadi efektivitas media promosi juga dapat diukur dengan peningkatan dari pengetahuan, sikap, dan praktik dari komunikan.

Tujuan dari penelitian ini yaitu untuk menganalisis hubungan pengetahuan ibu terhadap "isi piringku" dengan kejadian stunting pada anak balita usia 12-59 bulan di Desa Mendo Kecamatan Mendo Barat.

\section{METODE}

Penelitian ini menggunakan rancangan penelitian dengan cross sectional study. Penelitian dilakukan di Desa Mendo Kecamatan Mendo Barat. Pemilihan lokasi penelitian dilakukan berdasarkan fokus penanganan stunting di Kecamatan Mendo Barat yang dilaksanakan dari bulan Januari-Juni Tahun 2020.

Besar sampel dihitung dengan menggunakan rumus perhitungan yang dikembangkan oleh Lameshow, S. (1997) yang berjumlah 96 responden yang diambil secara acak menggunakan teknik simple random sampling. Instrumen yang digunakan dalam penelitian ini adalah kuesioner digunakan untuk mengukur pengetahuan ibu tentang isi piringku yang telah diuiji validitas dan reabilitasnya. Pengumpulan data dilakukan secara langsung melalui kader-kader balita menggunakan instrumen yang digunakan. Analisis data dilakukan dengan menggunakan teknik komputerisasi menggunakan uji chi-square.

Penelitian ini telah memperoleh Keterangan kelaikan etik dari Komisi Etik Penelitian Politeknik Kesehatan Pangkal Pinang dengan Nomor. 3/EC/KEPK/-PKP/IV/2020.

\section{HASIL}

Tabel 1. Distribusi Frekuensi Karakteristik Responden Penelitian

\begin{tabular}{lrr}
\hline \multicolumn{1}{c}{ Variabel } & n & \multicolumn{1}{c}{$\%$} \\
\hline Kelompok Umur & & \\
$18-21$ & 12 & 12,5 \\
$22-25$ & 19 & 19,8 \\
$26-29$ & 22 & 22,9 \\
$30-34$ & 18 & 18,8 \\
$35-38$ & 11 & 11,4 \\
$39-42$ & 11 & 11,4 \\
$43-46$ & 3 & 3,2 \\
Pendidikan Ibu & & \\
Tidak Sekolah & 4 & 4,2 \\
SD & 59 & 61,5 \\
SMP & 22 & 22,8 \\
SMA & 9 & 9,4 \\
Diploma/Sarjana & 2 & 2,1 \\
Pekerjaan Ibu & & \\
IRT & 85 & 88,5 \\
Wiraswasta & 4 & 4,2 \\
Petani & 5 & 5,2 \\
PNS/TNI/POLRI & 2 & 2,1 \\
Jenis Kelamin Balita & & \\
Laki-laki & 51 & 53,1 \\
Perempuan & 45 & 46,9 \\
\hline
\end{tabular}

Tabel 1 menunjukkan bahwa kelompok umur ibu terbanyak yaitu umur 26-29 tahun sebesar 22,9\% (22 orang) dengan pendidikan terbanyak adalah SD sebesar 61,5\% (59 orang). Paling banyak ibu balita merupakan ibu rumah tangga sebesar $88,5 \%$ (85 orang) dan terendah adalah PNS/TNI/POLRI sebesar 2,1\% (2 orang). Balita dengan jenis kelamin laki-laki sebesar $53,1 \%$ (51 orang) dan jenis kelamin perempuan sebesar $46,9 \%$ (45 orang)

Tabel 2. Distribusi Usia dan Tinggi Badan Balita 12-59 Bulan

\begin{tabular}{lrrr}
\hline \multicolumn{1}{c}{ Variabel } & Mean & \multicolumn{1}{c}{ SD } & Min-Maks \\
\hline $\begin{array}{l}\text { Usia Balita } \\
\text { (bulan) }\end{array}$ & 40,69 & 13.83 & $12-59$ \\
$\begin{array}{l}\text { Tinggi Badan } \\
(\mathrm{cm})\end{array}$ & 94,1 & 9.1 & $47.4-106$ \\
\hline
\end{tabular}

Berdasarkan tabel 2 bahwa dari 96 balita rata-rata usia balita adalah 40,69 bulan dan ratarata tinggi badan balita adalah $94,1 \mathrm{~cm}$.

Tabel 3. Distribusi Z-Score Berdasarkan Indeks TB/U Balita 12-59 Bulan

\begin{tabular}{lrrr}
\hline Variabel & Mean & \multicolumn{1}{c}{ SD } & \multicolumn{1}{c}{ Min-Max } \\
\hline \multirow{2}{*}{ Z-Score } & $-0,83$ & 1,559 & $(-2,87)-$ \\
& SD & SD & $(2,75)$ SD \\
\hline
\end{tabular}


Pada tabel 3 menunjukkan rata-rata nilai $z$ score balita adalah $-0,83$ SD dengan nilai minimum -2,87 SD dan maksimum 2,75 SD. Hasil penilaian z-score kemudian mengidentifikasi kejadian stunting balita menurut indikator $\mathrm{TB} / \mathrm{U}$.

Tabel 4. Distribusi $\begin{gathered}\text { Kejadian } \\
\text { Balita 12-59 Bulan }\end{gathered}$
\begin{tabular}{lrr}
\hline \multicolumn{1}{c}{ Status Gizi } & n & \multicolumn{1}{c}{$\%$} \\
\hline Pendek & 6 & 6,2 \\
Normal & 86 & 89,7 \\
Tinggi & 4 & 4,1 \\
\hline
\end{tabular}

Tabel 4 menunjukkan bahwa status gizi balita tertinggi adalah status gizi normal yaitu sebesar $89,7 \%$ ( 86 orang) dan terendah memiliki status gizi tinggi yaitu $4,1 \%$ (4 orang).
Tabel 5. Distribusi Pengetahuan Ibu Balita 12-59 Bulan tentang Isi Piringku

\begin{tabular}{lrr}
\hline \multicolumn{1}{c}{ Pengetahuan Ibu } & n & \multicolumn{1}{c}{$\%$} \\
\hline Tentang Isi Piringku & 62 & 64,6 \\
Baik & 25 & 26,0 \\
Kukup & 9 & 9,4 \\
\hline
\end{tabular}

Berdasarkan tabel 5 bahwa lebih banyak ibu balita yang memiliki pengetahuan baik tentang Isi Piringku yaitu sebesar 64,6\% (62 orang).

Analisis bivariat dilakukan dengan menghubungkan variabel independen dengan variabel dependen dengan menggunakan uji fisher exact sebagai berikut.

\section{Tabel 6. Hubungan Pengetahuan Ibu Tentang Isi Piringku dengan Kejadian Stunting pada Balita 12-59 Bulan

\begin{tabular}{|c|c|c|c|c|c|c|}
\hline \multirow{3}{*}{ Pengetahuan } & \multicolumn{3}{|c|}{ Kejadian Stunting } & \multirow{2}{*}{\multicolumn{2}{|c|}{ Jumlah }} & \multirow[b]{2}{*}{$p$-value } \\
\hline & Pendek & & mal & & & \\
\hline & n $\%$ & $\mathrm{n}$ & $\%$ & $\mathrm{n}$ & $\%$ & \\
\hline Baik & 4,5 & 63 & 95,5 & 66 & 100 & 0,373 \\
\hline Kurar & 10 & 27 & 90 & 30 & 100 & \\
\hline
\end{tabular}

Tabel 6 menunjukkan hasil analisis statistik antara pengetahuan ibu tentang isi piringku dengan kejadian stunting balita usia 1259 bulan yaitu ada sebesar $4,5 \%$ (3 orang) ibu dengan pengetahuan kurang dan memiliki balita stunting. Selain itu, ada sebesar $95,5 \%$ (63 orang) ibu memiliki pengetahuan baik tentang isi piringku memiliki balita dengan status gizi normal. Berdasarkan hasil uji fisher exact, diketahui bahwa tidak ada hubungan penegtahuan ibu tentang isi piringku dengan status gizi balita usia 12-59 bulan di Desa Mendo Kecamatan Mendo Barat dengan nilai $p$ value $=0,373$ ( $p$-value $>0,05)$.

\section{PEMBAHASAN}

Salah satu faktor yang dapat memengaruhi asupan makan seseorang adalah pengetahuan gizi yang akan berpengaruh terhadap status gizi seseorang. Pengetahuan gizi adalah pengetahuan terkait makanan dan zat gizi. Sikap dan perilaku ibu dalam memilih makanan yang akan dikonsumsi oleh balita dipengaruhi oleh berbagai faktor, diantaranya adalah tingkat pengetahuan seseorang tentang gizi sehingga dapat memengaruhi status gizi seseorang tersebut. Pengetahuan gizi ibu yang kurang dapat menjadi salah satu penentu status gizi balita karena menentukan sikap atau perilaku ibu dalam memilih makanan yang akan dikonsumsi oleh balita serta pola makan terkait jumlah, jenis dan frekuensi yang akan memengaruhi asupan makan pada bayi tersebut.

Pengetahuan gizi ibu dapat dipegaruhi oleh usia, pendidikan, pengetahuan, pekerjaan dan pendapatan. Selain itu, asupan makan pada balita juga dipengaruhi oleh budaya setempat yang juga dapat memengaruhi pemilihan makanan oleh ibu (Notoadmojo, 2008). Oleh karena itu, jika seorang ibu memiliki pengetahuan gizi yang kurang maka asupan makanan yang akan diberikan kepada balita juga kurang tepat dan dapat memengaruhi status balita tersebut.

Hasil penelitian ini menunjukkan sebagian besar tingkat pendidikan ibu balita adalah tamatan SD. Hal ini berarti kesadaran masyarakat akan pentingnya pendidikan bagi wanita masih kurang. Menurut Soetjiningsih (2014), pendidikan orang tua merupakan salah satu faktor yang penting dalam status gizi. Orang tua dapat menerima segala informasi dari luar tentang cara pengasuhan anak yang baik terutama bagai mana ibu memberikan makanan kepada anak, bagaimana menjaga kesehatan anak, pendidikannya, dan sebagainya. Makin banyak pengetahuan yang dimiliki dan perilaku yang diharapkan akan muncul pola asuh yang baik.

Menurut Nyoman (2013), tingkat pendidikan memiliki peranan penting untuk mendapatkan pekerjaan. Semakin tinggi 
pendidikan memiliki seseorang maka pekerjaan dan pendapatannya akan semakin meningkat. Jika dikaitkan dengan umur dan pendidikan memiliki pengaruh yang berkaitan.

Dalam penelitian ini kurangnya pengetahuan ibu tentang isi piringku dipengaruhi oleh pendidikan ibu. Tingkat pendidikan ibu akan memengaruhi sikap dan pola pikir ibu dalam memperhatikan asupan makanan balita mulai dari mencari, memperoleh dan menerima berbagai informasi mengenai pengetahuan tentang asupan makanan gizi balita sehingga akan memengaruhi pemilihan makanan yang akan menentukan status gizi balitanya (Nur, 2016). Hal ini didukung oleh sebuah penelitian Burhani, dkk (2016), yang mengatakan bahwa orang tua yang memiliki pendidikan tinggi lebih berorientasi pada tindakan preventif, lebih banyak mengetahui tentang masalah kesehatan yang lebih baik. Semakin tinggi pendidikan ibu, diharapkan ibu memiliki pengetahuan lebih baik dalam mengasuh anak. Penelitian Wahyuni (2009) juga menyebutkan bahwa terdapat hubungan pengetahuan ibu tentang gizi dengan status gizi balita.

Perilaku ibu tentang kesehatan dipengaruhi oleh beberapa faktor antara lain umur, pendidikan, status sosial, budaya, dan lain-lain (Notoadmojo, 2008). Perilaku ibu dalam pemberian gizi kepada balita juga dipengaruhi oleh status pekerjaan ibu. Ibu yang bekerja berdampak pada rendahnya waktu kebersamaan ibu dengan balita sehingga perhatian ibu terhadap perkembangan balita menjadi berkurang. Dampak dari ibu bekerja juga tergantung dari jenis pekerjaan yang dilakukan ibu. Ibu yang memiliki jenis pekerjaan berat maka akan mengalami kelelahan fisik sehingga ibu akan cenderung memilih untuk beristirahat daripada mengurus balitanya (Anggraini, 2008). Hal ini sejalan dengan penelitian Putri (2002) yang menyatakan bahwa ibu yang tidak bekerja dalam keluarga cenderung akan lebih banyak mempunyai waktu untuk memperhatikan makanan yang dikonsumsi keluarga dan mengasuh serta merawat anaknya. Ibu yang tidak bekerja akan memengaruhi asupan makanan anak karena peran ibu sebagai pengasuh dan pengatur konsumsi keluarga.

Menurut Lin (2008) tidak adanya hubungan antara pengetahuan ibu dengan perilaku ibu dikarenakan faktor kekerabatan sosial dan gotong royong di dalam budaya masyarakat yang mana pengaruh orang lain atau keluarga yang merawat bayi sangat kuat. Hal ini menyebabkan ibu-ibu yang bekerja sebagai buruh tani pada satu sampai dua minggu setelah melahirkan mereka membantu suaminya mencari nafkah sehingga bayi dititipkan ke keluarga terdekat.

Berdasarkan pengamatan terhadap responden, ibu tersebut sebenarnya sudah menerapkan frekuensi makan yang baik untuk anaknya, namun ibu tersebut tidak paham dengan apa yang dilakukannya. Hal ini dilatarbelakangi oleh tingkat pengetahuan, pendidikan, dan tingkat ekonomi yang baik. Semakin tinggi tingkat pendidikan orang tua maka semakin tinggi pula pengetahuan dan pengalamanya dalam merawat anaknya khususnya dalam pola pemberian makannya. Hal ini diperkuat oleh pernyataan Santoso (2010), apabila ibu rumah tangga memiliki pengetahuan gizi yang baik maka ibu akan mampu untuk memilih makananmakanan yang bergizi untuk dikonsumsi.

Pola makan pada balita sangat berperan penting dalam proses pertumbuhan pada balita, karena dalam makanan banyak mengandung gizi. Gizi menjadi bagian yang sangat penting dalam pertumbuhan. Gizi di dalamnya memiliki keterkaitan yang sangat erat hubungannya dengan kesehatan dan kecerdasan. Apabila terkena defisiensi gizi maka kemungkinan besar sekali anak akan mudah terkena infeksi. Gizi ini sangat berpengaruh terhadap nafsu makan. Jika pola makan tidak tercapai dengan baik pada balita maka pertumbuhan balita akan terganggu, tubuh kurus, pendek bahkan bisa terjadi gizi buruk pada balita (Purwani dan Mariyam, 2013).

Pola makan yang terbentuk sangat erat kaitannya dengan kebiasaan makan seseorang. Secara umum faktor yang memengaruhi terbentuknya pola makan adalah faktor ekonomi, faktor sosio budaya, agama, pendidikan dan lingkungan. Hasil penelitian Purwani dan Mariyam (2013) tentang pola pemberian makan dengan status gizi anak usia 1-5 tahun di Kabunan Taman Pemalang menemukan 45,5\% dari 33 anak balita pola makannya tidak baik sehingga dapat disimpulkan bahwa ada hubungan antara pola pemberian makan dengan status gizi anak usia 1-5 tahun di Kabunan Taman Pemalang.

Hal tersebut sejalan dengan hasil penelitian dari Damaiyanti, dkk (2016) tentang hubungan antara pola makan dengan status gizi pada balita di posyandu di Desa Manungga wilayah kerja Puskesmas Batulicin 1 Kecamatan Karang Bintang, 26,3\% dari 80 anak balita dengan pola makan tidak baik, maka dapat di ambil kesimpulan bahwa ada hubungan antara pola makan dengan status gizi pada balita di posyandu di Kecamatan Karang Bintang. Hal ini juga sejalan dengan penelitian dari Nasution, dkk 
(2018) yang menyimpulkan bahwa ada hubungan antara pola makan dengan status gizi sampel di Kelurahan Sunggal Kecamatan Medan Sunggal.

Status gizi merupakan gambaran kondisi fisik seseorang sebagai refleksi dari keseimbangan energi yang masuk dan yang dikeluarkan oleh tubuh (Marmi, 2013). Status gizi merupakan hasil akhir dari keseimbangan antara makanan yang masuk (nutrient input) dengan kebutuhan tubuh (nutrient output) akan zat gizi tersebut (Supariasa, 2012). Klasifikasi status gizi menurut Kementerian Kesehatan RI Tahun 2010 untuk indikator TB/U yaitu sangat pendek, pendek, normal dan tinggi.

Menurut Supariasa, dkk (2012), kelebihan dari indeks $(\mathrm{TB} / \mathrm{U})$ atau $(\mathrm{PB} / \mathrm{U})$ yaitu baik untuk menilai status gizi masa lampau, ukuran panjang dapat dibuat sendiri, murah dan mudah dibawa. Status gizi dipengaruhi oleh penyebab langsung (asupan makanan dan penyakit infeksi) dan penyebab tidak langsung (ketersedian pangan, pola asuh, pelayanan dan kesehatan lingkungan) (Kementerian Kesehatan RI, 2014). Menurut Mulyana (2013), faktor-faktor yang memengaruhi status gizi balita yaitu pendidikan ibu, pekerjaan orang tua, sosial ekonomi, akses kesehatan, hygiene sanitasi lingkungan, pola asuh, perilaku dan pengetahuan ibu.

Masalah gizi khususnya balita stunting dapat menghambat proses tumbuh kembang balita. Balita pendek memiliki dampak negatif yang akan berlangsung dalam kehidupan selanjutnya (UNICEF, 2012). Hasil penelitian diketahui bahwa balita yang mengalami masalah gizi stunting ada sebesar 6\% (6 orang). Faktor yang berhubungan dengan kejadian stunting pada balita adalah panjang lahir balita, riwayat ASI ekslusif, pendapatan keluarga, pendidikan ibu dan pengetahuan gizi ibu terhadap kejadian stunting pada balita (Ni'mah dan Nadhiroh, 2015).

Menurut Munawaroh (2015) kejadian stunting dipengaruhi oleh pola asuh ibu dalam pemberian makan anak. Maka dapat dikatakan ibu yang memberikan perhatian lebih terhadap anaknya dalam hal pemberian makanan akan berpengaruh positif kepada keadaan status gizi anak. Pola asuh dalam memberikan makanan sehari-hari penting untuk menunjang pertumbuhan balita.

Isi piringku adalah suatu metode panduan makan sehat yang dikenalkan oleh Kementerian Kesehatan yang dapat menjadi acuan sajian sekali makan. Sebab makan bukan hanya sekedar kenyang, namun juga harus memenuhi kebutuhan nutrisi tubuh. Keragaman makanan dalam satu piring merupakan hal yang tak bisa ditawar, mencakup protein, karbohidrat, vitamin, dan mineral seimbang. Keberagaman penting karena tidak ada satupun jenis makanan yang mengandung semua jenis zat gizi yang dibutuhkan tubuh. Dalam satu porsi sajian, sayursayuran dan buah-buahan disarankan porsinya adalah separuh bagian piring. Separuh bagian piring lainnya dapat diisi dengan karbohidrat dan protein (Kementerian Kesehatan RI, 2014).

Menurut penelitian Renata dan Dewajanti (2017), bahwa pengetahuan dan sikap akan memengaruhi perilaku anak terhadap gizi seimbang. Dengan perilaku yang baik, anak akan mendapatkan asupan gizi yang seimbang sehingga status gizi anak tersebut akan baik. Salah satu cara untuk membantu terjadinya perubahan masyarakat sesuai dengan menggunakan bantuan media massa atau sumber informasi lain (Kementerian Kesehatan RI, 2014).

Hasil penelitian ini menunjukkan tidak ada hubungan pengetahuan ibu tentang isi piringku dengan status gizi balita usia $12-59$ bulan Di Desa Mendo Kecamatan Mendo Barat. Hal ini terjadi karena beberapa responden memiliki balita dengan status gizi normal tetapi responden memiliki pengetahuan yang kurang tentang isi piringku, begitupun sebaliknya responden memiliki balita dengan status gizi pendek (stunting) tetapi responden memiliki pengetahuan yang baik tentang isi piringku. Hal ini dipengaruhi oleh beberapa faktor, seperti faktor ekonomi atau pekerjaan, pendidikan, umur dan lingkungan.

Dalam penelitian ini, ibu balita yang memiliki pengetahuan cukup baik tentang isi piringku namun tidak menerapkannya dalam kehidupan sehari-hari ternyata dipengaruhi oleh pekerjaan dan pendapatan keluarga. Menurut Mulyana (2013), ada pengaruh yang signifikan antara pendapatan orang tua dengan status gizi. Keluarga yang mempunyai pendapatan yang rendah sulit memenuhi kebutuhan makanan apalagi berbagai jenis makanan yang beragam. Kemampuan keluarga untuk mencukupi kebutuhan makanan juga tergantung dari harga bahan makanan. Bahan makanan yang berharga mahal biasanya jarang terbeli dan bahkan tidak terbeli.

Hal ini sejalan dengan penelitian yang dilakukan oleh Mahardika mengenai hubungan anatara pendapatan keluarga dan pengetahuan gizi ibu dengan status gizi balita di Desa Selodoko Kecamatan Ampel Kabupaten Boyolali yang menyatakan bahwa pengetahuan gizi ibu dengan status gizi balita mempunyai nilai $p$ value $=0,110$ sehingga tidak ada hubungan antara 
pengetahuan ibu dengan status gizi balita (Mahardika, 2012).

\section{SIMPULAN}

Berdasarkan hasil penelitian, maka dapat disimpulkan bahwa ibu balita dalam penelitian ini lebih banyak yang memiliki pengetahuan yang baik tentang isi piringku dan masih terdapat balita yang mengalami masalah gizi stunting (pendek). Hasil analisis menunjukkan bahwa tidak ada hubungan pengetahuan ibu tentang isi piringku dengan status gizi balita usia 12-59 bulan di Desa Mendo Kecamatan Mendo Barat.

\section{DAFTAR PUSTAKA}

Almatsier, Sunita. (2012). Prinsip Dasar Ilmu Gizi. Jakarta: Gramedia Pustaka Umum.

Al-Shookri, Layla Al-Shukaily, Fouad Hassan, Sadeq Al-Sheraji, Saif Al-Tobi. (2011). Effect of Mothers Nutritional Knowledge and Attitudes on Omani Children's Dietary Intake. Oman Medical Journal, 26(4), 253 257.

Anggraini, S. D. (2008). Hubungan Antara Tingkat Pengetahuan Ibu Tentang Makanan Bergizi Dengan Status Gizi Balita Usia 1-3 Tahun di Desa Lencoh Wilayah Kerja Puskesmas Selo Boyolali. [Skripsi]. Surakarta: Fakultas Ilmu Kesehatan, Universitas Muhammadiyah Surakarta.

Burhani PA, Oenzil F, Revilla G. (2016). Hubungan Tingkat Pengetahuan Ibu dan Tingkat Ekonomi Keluarga Nelayan dengan Status Gizi Balita di Kelurahan Air Tawar Kota Padang. Jurnal Kesehatan Andalas. 5 (3), 515-521.

Damaiyanti, A., Widia, L., Ningsih, R., \& Bumbu, K. K. B. K. T. (2016). Hubungan Antara Pola Makan Dengan Status Gizi Pada Balita Di Posyandu Desa Manunggal Wilayah Kerja Puskesmas Batulicin 1 Kecamatan Karang Bintang. Jurnal Darul Azhar, 1(1), 63-68.

Dinas Kesehatan Provinsi Kepulauan Bangka Belitung. (2017). Profil Kesehatan Provinsi Kepulauan Bangka Balitung Tahun 2017. Bangka Belitung: Dinas Kesehatan Provinsi Kepulauan Bangka Belitung.

Direktorat Jenderal Bina Gizi Masyarakat. (2018). Buku Saku Pemantauan Status Gizi dan Indikator Kinerja Gizi Tahun 2017. Jakarta: Kementerian Kesehatan RI 2018.

Global Nutrition Report. (2014). Action and Accountability to Accelerate The World's on Nutrition. Washington, DC: International Food Policy Research Institutet.
Kementerian Kesehatan RI. (2010). Rencana Strategis Kementerian Kesehatan Tahun 2010-2014. Jakarta.

Kementerian Kesehatan RI. (2014). Pedoman Umum Gizi Seimbang. Jakarta: Direktorat Jenderal Bina Gizi dan KIA.

Lameshow, S. (1997). Besar Sampel dalam Penelitian Kesehatan. Yogyakarta: Universitas Gadjah Mada.

Lin D.Y. (2008). Hubungan Pengetahuan dan Sikap Ibu Dengan Pemberian Asi Ekslusif. [Tesis]. Surakarta: Program Studi Kedokteran Keluarga, Universitas Sebelas Maret.

Mahardika, A. (2012). Hubungan antara Pendapatan Keluarga dan Pengetahuan Gizi Ibu dengan Status Gizi Balita Di Desa Selodoko Kecamatan Ampel Kabupaten Boyolali. [Skripsi]. Surakarta: Universitas Muhammadiyah Surakarta.

Marmi. (2013). Gizi Dalam Kesehatan Reproduksi. Yogyakarta : Pustaka Pelajar.

Mulyana, D. W. (2013). Pengaruh Tingkat Pengetahuan, Pendidikan, Pendapatan, dan Perilaku Ibu Terhadap Status Balita Gizi Buruk di Kecamatan Tegalsari dan di Kecamatan Tandes Kota Surabaya. Swara Bhumi, 2(2), 1-10.

Mulyono, S. (2000). Perilaku Kebersihan Lingkungan Siswa Sekolah Dasar Dihubungkan dengan Pengetahuan Kebersihan Lingkungan dan Persepsi tentang Pengawasan Guru. Majalah Kesehatan Masyarakat, 6(2), 10-13.

Munawaroh, S. (2015). Pola Asuh Mempengaruhi Status Gizi Balita. Jurnal Keperawatan. 6 (1), 44-50.

Nasution, Henna Sultana, dkk. (2018). Hubungan Pola Makan dengan Status Gizi pada Anak Balita Di Wilayah Kerja Puskesmas Medan. Jurnal Kesehatan Masyarakat dan Lingkungan Hidup. 1 (1), 15-21.

Ni'mah, K., \& Nadhiroh, S. R. (2015). Faktor yang berhubungan dengan kejadian 
stunting pada balita. Media Gizi Indonesia, 10(1), 13-19.

Notoatmodjo, S. (2008). Pendidikan dan Perilaku Kesehatan. Jakarta: Rineka Cipta.

Nur. (2016). Hubungan Pengetahuan Ibu Tentang Pemberian Nutrisi Terhadap Status Gizi Anak Toodler di Desa Gonilan. [Skripsi]. Surakarta: Universitas Muhammadiyah Surakarta.

Nyoman, Arya. (2013). Hubungan Tingkat Pendidikan dan Umur Terhadap Pekerjaan. [Skripsi]. Yogyakarta: Universitas Negeri Yogyakarta.

Purwani, E., \& Mariyam. (2013). Pola Pemberian Makan Dengan Status Gizi Anak Usia 1 Sampai 5 Tahun Di Kabunan Taman Pemalang. Jurnal Keperawatan Anak. 1(1), 30-36.

Putri. (2002). Hubungan Tingkat Pendidikan Ibu, Tingkat Ekonomi Keluarga Nelayan dengan Status Gizi Balita Di Desa Pauh Barat Kabupaten Padang Pariaman. [Skripsi]. Padang: Universitas Andalas.

Rahmawati I, Sudargo T, Paramastri I. (2018). Pengaruh Penyuluhan dengan Media Audio Visual Terhadap Peningkatan Pengetahuan Sikap dan Perilaku Ibu Balita Gizi Kurang dan Buruk di Kabupaten Kotowaringin Barat Provinsi Kalimantan Tengah. Jurnal Gizi Klinik Indonesia. 4(2), 69-77.
Renata P, Dewajanti A.M. (2017). Hubungan Pengetahuan, Sikap, dan Perilaku Tentang Gizi Hubungan Pengetahuan, sikap, Perilaku Tentang Gizi Seimbang dengan Status Gizi Siswa Kelas IV dan V di Sekolah Dasar Tarakanita Gading Serpong. Jurnal Kedokteran Medik. 23(1), 60-68.

Santoso. (2010). Kesehatan dan Gizi. Jakarta: Rineka Cipta.

Soetjiningsih. (2014). Tumbuh Kembang Anak. Jakarta: EGC.

Supariasa. (2012). Pendidikan dan Konsultasi Gizi. Jakarta: EGC.

Supariasa, I.D.N., Bakri, B., dan Fajar, I. (2012). Penilaian Status Gizi. Jakarta: EGC.

UNICEF. (2012). Ringkasan Kajian Gizi. Jakarta: Pusat Promosi Kesehatan, Kementerian Kesehatan RI.

Wahyuni, I. (2009). Hubungan Tingkat Pengetahuan Ibu tentang Gizi dengan Status Gizi Anak Balita Di Desa Ngemplak Kecamatan Karangpandan Kabupaten Karanganyer. [Skripsi]. Surakarta: Universitas Sebelas Maret.

Yabanci N., Kisac I., Karakus S. (2014). The effects of mother's nutritional knowledge on attitudes and behaviors of children about nutrition. Procedia - Social and Behavioral Sciences.116 (2), 4477-4481. 